\title{
Professor Renato Helios Migliorini, Pioneiro na Investigação em Ácidos Graxos
}

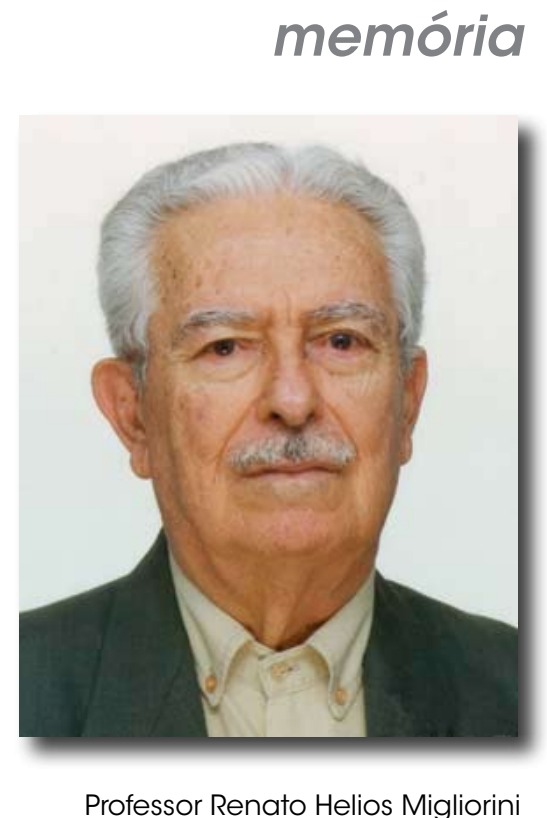

EDER C. R. QUINTÃO

Professor Emérito de Clínica Médica da Faculdade de Medicina da Universidade de São Paulo (FMUSP), ex-titular da Disciplina de Endocrinologia da FMUSP, São Paulo, SP, Brasil.

Recebido em 12/02/2008 Aceito em 13/02/2008
MA BREvísSIMA NOTícIA, DIVULGada on-line pela Universidade de São Paulo, comunicou o falecimento, em 16 de janeiro deste ano, de Renato Helios Migliorini, sepultado em Ribeirão Preto onde viveu a maior parte de seus 82 anos.

Nascido em Jaú em 1926, graduou-se pela Faculdade de Medicina da USP em 1949 e obteve seu doutoramento com a tese "Efeito de estrógenos no diabetes produzido por pancreatectomia total em ratos", que prenunciava sua sistemática atividade futura. Em 1953, era o primeiro contratado em dedicação exclusiva do Departamento de Fisiologia da Faculdade de Medicina de Ribeirão Preto. Fez pós-doutorado na Universidade da Califórnia como bolsista da Fundação Rockefeller em 1959/1960, uma distinção só outorgada por inquestionável mérito na era pré-Fapesp (Fundação de Amparo à Pesquisa do Estado de São Paulo) a talentos muito especiais.

Dizer que foi vice-diretor daquela Faculdade, diretor da Faculdade de Filosofia, Ciências e Letras de Ribeirão Preto (FFCLRP) da USP, produziu mais de uma centena de trabalhos em revistas internacionais de destaque, principalmente no American Journal of Physiology, foi citado mais de mil vezes, homenageado em vários fóruns, como seu prêmio SBEM de 1996, comendador da Ordem Nacional do Mérito Científico do governo brasileiro e membro titular da Academia Brasileira de Ciências, entre outras distinções, ou que formou considerável número de mestres e doutores, é pouco por não traduzir o caráter, o âmago do homem, seu devotado amor à ciência e à sua Faculdade que o mantiveram ativo por mais de dez anos como professor emérito, período em que publicou parte substancial de sua obra científica.

Parar, não podia! Impensável para este homem que se inquietava com o que produzia, eterno insatisfeito, crítico mais severo de sua própria obra como confessava sem cerimônia, com a mais natural simplicidade - não por insegurança pessoal ou timidez, mas por sentir que pesquisa, principalmente biológica, é repleta de incertezas inerentes e sempre sujeita às armadilhas experimentais. Percebê-las era privilégio de mentes agudamente alertas, como a do Migliorini que conhecemos. Crítico de si próprio, também não tolerava a mediocridade; foi assim que o ouvi comentar, como de costume, a voz baixa, após uma conferência científica que havíamos assistido de um clínico de fama, também professor: "teria sido uma palestra compreensível se ousasse fazer perguntas com clareza". Isso, como tudo mais, dizia em frases lúcidas precedidas por um fugaz instante de silêncio, como se hesitante, pausado, calmo, despretensiosamente carregando seu meio sorriso suave em uma fisionomia austera e tranqüila.

O legado de Migliorini para a ciência foi o caminhar coerente, metódico, buscando elucidar cada processo fisiológico, etapa por etapa, dos mecanismos neurais de regulação do metabolismo plasmático e tissular de ácidos graxos e glicose, o papel dos estados de jejum e alimentar nesta regulação, seu controle 
no tecido adiposo marrom, além do metabolismo de proteínas no tecido muscular, as interações da proteína e da glicose alimentar na glicólise no tecido adiposo, as ações metabólicas neste tecido por exposição ao frio e fármacos, e muitas mais variações sobre o tema. Quem pensaria, senão uma mente incontrolavelmente curiosa, em usar tantas espécies animais distintas - ratos, codornas, peixes, sapos, serpentes - como modelos experimentais úteis para compreensão da fisiologia/bioquímica humana, incluindo investigar a neoglicogênese em um animal estritamente carnívoro, como os abutres. Migliorini mostrou-nos que isso só é possível com uma equipe coesa, unida em propósitos e ideais, edificada sobre mútuo respeito, na qual se contavam muitos e leais companheiros, como Isis do Carmo Ketelhut, José Antunes Rodrigues, José Ernesto dos Santos, Itamar Vugman, Cecílio Linder, Jorge Gross, Ingrid Dick de Paula, Vera Lúcia Teixeira, além dos já falecidos César Timo Iaria, André Ricciardi Cruz, Cássio Botura e Miguel Rolando Covian, apenas para citar alguns de meu limitado conhecimento, claro que sob o risco de ter omitido tantos outros igualmente cruciais ao seu trabalho.
Essa obra ímpar foi coroada pela vida afetiva familiar. Casado desde 1953 com Emília Blat Migliorini, viveu inconsolável viuvez depois de 40 anos, tendo gerado quatro filhos: Renato, Maria Cecília, Vera Lúcia e Valéria, e destes, seis netos. Vera Lúcia confidenciou-me que Renato aprendeu a amar a música com o piano de Emília Blat, colaborou na Fundação Pró-Música de Ribeirão Preto para a realização de concertos com músicos consagrados e dedicou-se com afinco à vinda da Escola de Música da USP para Ribeirão Preto, no topo de ser leitor assíduo. Soubessem destas outras qualificações, seus amigos e admiradores, ainda que distantes de Ribeirão Preto, teriam usufruído melhor ainda de seu convívio. Por tudo isso, inimaginável passar despercebida a passagem deste exemplar e dedicado operário da ciência.

\section{Endereço para correspondência:}

Eder C. R. Quintão

Faculdade de Medicina da USP

Av. Dr. Arnaldo, 455, sala 3305 - LIM 10

01246-000 São Paulo, SP

E-mail: lipideq@usp.br 